\title{
FACTORS AFFECTING FORWARD PRICING BEHAVIOUR: IMPLICATIONS OF ALTERNATIVE REGRESSION MODEL SPECIFICATIONS
}

\author{
H Jordaan and B Grové \\ Department of Agricultural Economics, University of the Free State \\ Accepted September 2009
}

\begin{abstract}
Price risk associated with maize production became a reason for concern in South Africa only after the deregulation of the agricultural commodities markets in the mid-1990s, when farmers became responsible for marketing their own crops. Although farmers can use, inter alia, the cash forward contracting and/or the derivatives market to manage price risk, few farmers actually participate in forward pricing. A similar reluctance to use forward pricing methods is also found internationally. A number of different model specifications have been used in previous research to model forward pricing behaviour which is based on the assumption that the same variables influence both the adoption and the quantity decision. This study compares the results from a model specification which models forward pricing behaviour in a single-decision framework with the results from modelling the quantity decision conditional to the adoption decision in a two-step approach. The results suggest that substantially more information is obtained by modelling forward pricing behaviour as two separate decisions rather than a single decision. Such information may be valuable in educational material compiled to educate farmers in the effective use of forward pricing methods in price risk management. Modelling forward pricing behaviour as two separate decisions is thus a more effective means of modelling forward pricing behaviour than modelling it as a single decision.
\end{abstract}

JEL Q13

\section{1}

\section{Introduction}

From the early 1930s until the mid-1990s, the South African agricultural sector underwent a long period of state intervention (Meyer, 2005). Farmers were guaranteed a fixed producer price at the beginning of the production season, irrespective of the transaction costs incurred, because of the varying distances to final destinations for the delivery of products (Meyer, 2005). This period of regulation ended with the Marketing of Agricultural Products Act of 1996, which resulted in the demise of most of the control boards. The Act created an environment in which farmers, traders, and processors could react positively to transparent, market- oriented prices. During the period of regulation, cooperatives were the only legal marketing agents (Meyer, 2005). However, the deregulation of the agricultural commodity markets made producers responsible for marketing their own produce (Bown, Ortmann \& Darroch, 1999). Since control boards had handled all marketing activities prior to deregulation, agribusinesses had gained very little experience in the 'art' of commercial grain marketing, and those involved in buying and selling maize were left in considerable uncertainty about price movements (van Rooyen, 1999). The deregulation of the South African maize market in the mid-1990s proved to have a substantially positive impact on the volatility of the price of maize in South Africa (Jordaan, Grové, Jooste \& Alemu, 
2007). Greater efficiency and competition in the marketing chain, together with the emergence of viable market mechanisms for the management of price risk, were all expected to militate against this higher volatility (Bayley, 2000).

Three main markets for grain have emerged in South Africa. Producers may now sell their crop to whomever they choose and at whatever price they can get in the cash (spot) market. Alternatively, they can forward contract some or all of their maize in the cash forward contracting market, or else they can use futures contracts and/or options to hedge against price risk in the derivatives market (Bown, Ortmann \& Darroch, 2000). Although the cash market is a userfriendly strategy with significant liquidity benefits (Isengildina \& Hudson, 2001), marketing on a cash basis is often considered a risky alternative, because producers have no control over the market price. The use of forward pricing methods can reduce the farmer's exposure to the risk that the price may be lower than the expected price range on which the production decision was based. However, despite the importance of price risks to a farm business, and although farmers can effectively manage price risk by using forward pricing methods, few international farmers seem to use it (Asplund, Forster \& Stout, 1989; Goodwin \& Schroeder, 1994; Musser, Patrick \& Eckman, 1996; Sartwelle, O'Brien, Tieney \& Eggers, 2000; Isengildina \& Hudson, 2001). Bown et al. (2000) investigated South African maize producers' use of forward pricing methods and found that 47.1 per cent of respondents used some form of forward pricing arrangements during 1998/99. Jordaan and Grové (2007) investigated South African maize producers' forward pricing behaviour during the 2004/05 season. They expected an increase in the number of farmers who participated in forward pricing owing to a learning curve effect. However, they found that only 44 per cent of their respondents participated in some form of forward pricing. Clearly there has been no significant increase in participation among South African maize producers over the past years, as had originally been expected.

Katchova and Miranda (2004) distinguish between two types of decisions that farmers make when deciding on their marketing strategy.
The first is whether or not to use forward pricing instrument, and the second is to decide on the quantity, frequency, and contract type. Various model specifications have been used internationally to study these decisions. Tobit models have been used to model decisions on the proportion of the crop a farmer should forward price (Goodwin \& Schroeder, 1994; Musser et al., 1996; Shapiro \& Brorsen, 1998; Sartwelle et al., 2000), while farmers' choices of cash sales, cash forward contracts and futures/ options have been modelled using multinomial logit models (Isengildina \& Hudson, 2001; Sartwelle et al., 2000). Bown et al. (2000) acknowledged that farmers may use multiple marketing channels, and derived a continuous index of the use of price risk management tools, which was explained by personal and business characteristics using Ordinary Least Squares (OLS) regression analysis. In essence, all of these studies modelled forward contracting behaviour within a single decision-making framework, whereby the implicit assumption is that the same variables influence both the adoption and the extent of use of forward pricing methods in a similar way. Katchova and Miranda (2004) argue that failure to acknowledge that variables may influence the two forward pricing decisions differently may bring about misleading conclusions as to the influence of personal and farm characteristics on these two forward pricing decisions. They proposed the use of a two-step econometric approach to allow a variable to influence the adoption decision and the quantity forward priced differently. The results obtained by Jordaan and Grové $(2007 ; 2008)$ also suggest that the same variables may influence the adoption and quantity decisions differently. In their analyses, they used a Logit model to model the adoption decision and OLS to model the quantity forward priced. Unfortunately, there is no relationship between the Logit and OLS model specifications, and it is impossible to statistically test the model specifications used by these researchers. It is therefore impossible to generalise their results, which indicates that adoption and quantity decisions are influenced by separate variables.

The objective of this study is to make a formal comparison between the results obtained when 
modelling the forward pricing behaviour of Vaalharts maize farmers within a single decisionmaking framework in comparison with modelling the quantity decision conditional to the adoption decision as proposed by Katchova and Miranda (2004) in their two-step econometric approach. The single decision-making framework is applied by estimating a Tobit model of the quantity of maize crop forward contracted. The results are then compared with the more general Cragg's model specification, whereby the adoption decision is modelled with a Probit model and the quantity forward price is modelled with a truncated regression model. The Cragg's model specification allows for formal testing of the alternative model specifications using a loglikelihood ratio statistic (Greene, 2008).

The rest of the paper is structured as follows: the data that were used in the analyses and the procedures followed in meeting the objective of this study are discussed in the next section. The results are then presented and discussed, followed by the conclusions and some recommendations for further research.

\section{2}

\section{Data and procedures}

\subsection{Data}

The same dataset compiled by Jordaan and Grové (2007) is used in this study to compare alternative model specifications for studying the forward pricing behaviour of Vaalharts maize producers. ${ }^{1}$ Primary data were obtained by means of a questionnaire survey conducted in the Vaalharts irrigation scheme during October 2005. Only farmers in the Northern Canal region were included in the sample, since the Northern Canal region is by far the most important commercial production region in the irrigation scheme. To be consistent with guidelines for sampling size, as proposed by Strydom, Fouché and Delport (2003) $78^{2}$ farmers were randomly drawn from an existing database of Vaalharts Water. The farmers were personally interviewed to complete the questionnaire to ensure a sufficiently high response rate. Only 50 of the respondents planted maize during the 2004/05 season, and they were studied further. ${ }^{3}$ The questionnaire gathered information on the personal and business characteristics of the farmers as well as on their marketing behaviour during the 2004/05 season. The personal characteristics include, inter alia, the age and experience of the farmers, their marketing skills and their attitudes to risk. Regarding their business characteristics, they were asked to provide information on their level of specialisation in production practices, and their use of centre pivot irrigation technology and other risk management tools. Table 1 presents a summary of some of the respondents' personal and business characteristics. A distinction is made between those respondents who adopted forward pricing methods (futures contracts and/or options) and those who did not.

\section{Table 1:}

Summary of some of the personal and business characteristics of the sample of Vaalharts maize producers with a distinction made between respondents who adopted forward pricing methods and those who did not

\begin{tabular}{|c|c|c|c|c|}
\hline \multirow[b]{2}{*}{ Characteristics } & \multicolumn{2}{|c|}{ Adopters $(n=22)$} & \multicolumn{2}{|c|}{ Non-adopters $(\mathrm{n}=\mathbf{2 8})$} \\
\hline & Mean & $\begin{array}{l}\text { Standard } \\
\text { deviation }\end{array}$ & Mean & $\begin{array}{l}\text { Standard } \\
\text { deviation }\end{array}$ \\
\hline Age (years) & 51.16 & 10.11 & 49.82 & 10.71 \\
\hline Tertiary education (Yes/No) & 0.54 & 0.50 & 0.57 & 0.50 \\
\hline Experience (Years) & 23.06 & 12.16 & 21.36 & 10.80 \\
\hline Marketing skills (1-7) & 4.37 & 0.87 & 4.02 & 1.08 \\
\hline
\end{tabular}




\begin{tabular}{|c|c|c|c|c|}
\hline Off-farm economic activities (\%) & 0.12 & 0.22 & 0.13 & 0.24 \\
\hline Insurance (Yes/No) & 0.91 & 0.28 & 0.64 & 0.48 \\
\hline $\begin{array}{l}\text { Specialisation (index where } 1= \\
\text { specialisation in one crop) }\end{array}$ & 0.33 & 0.12 & 0.34 & 0.16 \\
\hline Proportion of farmland rented (\%) & 0.18 & 0.24 & 0.27 & 0.88 \\
\hline Centre pivot adoption (Yes/No) & 0.87 & 0.33 & 0.50 & 0.50 \\
\hline Yield risk premium* & 14.20 & 12.58 & 15.97 & 15.49 \\
\hline Forward price perception (Yes/No) & 0.79 & 0.41 & 0.64 & 0.48 \\
\hline Free market preference $(1-7)$ & 3.91 & 2.63 & 3.23 & 2.67 \\
\hline
\end{tabular}

* The yield risk premium is a proxy for the respondent's level of risk aversion. It is the proportion of the current expected yield that a respondent is willing to sacrifice for the opportunity to produce a crop with a constant yield (Musser et al., 1996).

Source: Jordaan and Grové (2007).

An unexpected feature in Table 1 is the lower average yield risk premium of the adopters in comparison with that of the non-adopters. The lower-yield risk premium implies that, on average, farmers who have adopted the use of forward pricing methods are less risk-averse than those who decided not to use forward pricing methods. Further, the scores of the variables related to human capital on average differ more between adopters and non-adopters than with other variables. Those variables include the farmers' marketing skills, the proportion of farmland which is rented, the use of centre pivot irrigation technology and farmers' preference for the free market system to a regulated marketing system. As shown in Table 1, there is some evidence that human capital should have an influence on forward pricing behaviour.

\subsection{Procedures}

Within a single decision-making framework the dependent variable is classified as the proportion of maize that is forward priced. Since non-adopters forward price zero per cent of their maize, the dependent variable is censored at a threshold of zero. Censoring makes the OLS estimated parameters biased and inconsistent (Heij, de Boer, Hans-Franses, Kloek \& van Dijk, 2004; Gujarati, 2003; Greene, 2008) and most researchers (Goodwin \& Schroeder, 1994; Musser et al., 1996; Shapiro \& Brorsen, 1998; Sartwelle et al., 2000) have used the Tobit model specification to overcome the problem. A critical underlying assumption of the Tobit model is that a variable that increases the probability of adoption also increases the average quantity forward price (Lin \& Schmidt, 1984). Thus, the same variables influence adoption and the quantity forward price in the same direction.

Cragg (1971) proposed a more general model specification that allows the same variable to influence the adoption and quantity forward price differently. Following Greene (2008), the Cragg model is specified as follows:

Adoption equation

$$
\begin{array}{ll}
\operatorname{Pr}\left[y_{i}^{*}>0\right]=\Phi\left(x_{i} \gamma\right), & z_{i}=1 \text { if } y_{i}^{*}>0 \\
\operatorname{Pr}\left[y_{i}^{*} \leq 0\right]=1-\Phi\left(x_{i}^{*} \gamma\right), & z_{i}=0 \text { if } y_{i}^{*} \leq 0
\end{array}
$$

Nonlimit quantity decision

$E\left[y_{i} \mid z_{i}=1\right]=x_{i} \beta+\sigma \lambda_{i}$

where: $\gamma$ and $\beta$ are coefficients to be estimated, $y$ is the observed use of forward pricing and $x$ represents the factors which are hypothesised to affect forward pricing behaviour.

In essence, the Cragg model specification is a combination of the univariate Probit model (equation 1) and a truncated regression model (equation 2), which can be estimated independently. ${ }^{4}$ An underlying feature of the specification is that it reduces to the Tobit model if $\gamma=\frac{\beta}{\sigma}$ which causes the variables to influence the adoption and forward pricing decisions in 
the same manner. This restriction can be tested by estimating the Tobit, Probit and truncated regression models separately, using the same variables and then computing the following loglikelihood test statistic (Greene, 2008):

$\lambda=2\left(\ln L_{\text {Probit }}+\ln L_{\text {Truncated regression }}-\ln L_{\text {Tobit }}\right)$

where $\lambda$ is distributed chi-squared with $r$ degrees of freedom.

\section{Hypothesised explanatory variables}

Table 2 summarises the variables that were hypothesised to influence forward pricing behaviour. Brief descriptions of each variable and the expected direction of the influence of the hypothesised variable on the use of forward pricing methods are also shown in Table 2.

\section{Table 2:}

Variables expected to influence the quantity decision and the expected signs of the influence of the variables on the quantity decision

\begin{tabular}{|c|c|c|}
\hline Variable & Description & Expected sign \\
\hline Insurance & $\begin{array}{l}\text { Dummy variable scoring } 1 \text {, if respondent used crop insurance, } \\
\text { otherwise } 0 .\end{array}$ & $+/-$ \\
\hline $\begin{array}{l}\text { Centre pivot } \\
\text { adoption }\end{array}$ & $\begin{array}{l}\text { Dummy variable scoring } 1 \text {, if respondent adopted centre pivot } \\
\text { technology, otherwise } 0 .\end{array}$ & $+/-$ \\
\hline $\begin{array}{l}\text { Off-farm economic } \\
\text { activities }\end{array}$ & $\begin{array}{l}\text { Proportion of total income that was generated from off-farm } \\
\text { economic activities (\%). }\end{array}$ & $+/-$ \\
\hline Specialisation & $\begin{array}{l}\text { Level of diversification (index compiled by summing the squared } \\
\text { proportional contributions of all enterprises to the total farm } \\
\text { income. A value of } 1 \text { indicates the specialisation in the production } \\
\text { of } 1 \text { crop). }\end{array}$ & $+/-$ \\
\hline Experience & Number of years of farming experience of the respondent. & $+/-$ \\
\hline Marketing skills & $\begin{array}{l}\text { Respondent's self-rating of his/her marketing skills relative to that of } \\
\text { other farmers in the region (measure on scale from } 1 \text { (much lower) } \\
\text { to } 7 \text { (much higher)). }\end{array}$ & $+/-$ \\
\hline Risk aversion & $\begin{array}{l}\text { Level of risk aversion measured by means of a yield risk premium } \\
\text { (proportion of current expected yield that respondent is willing to } \\
\text { sacrifice for opportunity to produce crop with constant yield). }\end{array}$ & + \\
\hline $\begin{array}{l}\text { Forward pricing } \\
\text { perception }\end{array}$ & $\begin{array}{l}\text { Dummy variable scoring } 1 \text {, if respondent perceives forward pricing } \\
\text { to be effective in reducing price risk, otherwise } 0 .\end{array}$ & + \\
\hline $\begin{array}{l}\text { Free market } \\
\text { preference }\end{array}$ & $\begin{array}{l}\text { Rating of respondent's preference for a free market rather than } \\
\text { a market regulated by government on a scale from } 1-7 \text { with } 7 \\
\text { indicating a } 100 \% \text { preference for the free market. }\end{array}$ & + \\
\hline $\begin{array}{l}\text { Proportion farmland } \\
\text { rented }\end{array}$ & Proportion of farmland rented (\%). & + \\
\hline Tertiary education & $\begin{array}{l}\text { Dummy variable scoring } 1 \text { if respondent has some form of tertiary } \\
\text { education, otherwise } 0 .\end{array}$ & + \\
\hline
\end{tabular}

Table 2 shows that the expected direction of the influence of a number of variables is ambiguous. A large proportion of those variables are alternative risk management tools. The use of alternative risk management tools influences the overall risk of investing in farming (Bown et al., 2000). The direction of the influence, however, depends on whether the alternative tool is used 
complementarily with forward pricing or as a substitute for it. The alternative tools considered in this study include the use of crop insurance, centre pivot irrigation technology, off-farm economic activities and crop diversification, which is the inverse of specialisation. The remaining variables that may influence the use of forward pricing methods either positively or negatively are farming experience and the marketing skills of the farmer. Farmers with more years of farming experience may be in a healthier financial position, allowing them to try out new marketing techniques (Davis, 2005). However, because those with more years of farming experience may be more accustomed to the previous regime of market regulation in South Africa, they may be more reluctant to employ new marketing technologies. With reference to the farmer's marketing skills, farmers who rate their marketing skills higher than those of others may consider this sufficient for using new marketing techniques, thus the positive expected relationship. On the other hand, farmers who perceive their marketing skills to be insufficient are likely to employ a marketing agent to handle marketing decisions. The marketing agent is, however, likely to use the more sophisticated marketing techniques like forward pricing.

The remaining variables are hypothesised as having a positive influence on the use of forward pricing methods. First, expected utility theory suggests that risk aversion should be positively related to the use of available tools to reduce their exposure to risk. Because price risk is an important component of the overall variability in profit (Groenewald, Geldenhuys, Jooste, Balyamujura \& Doyer, 2003), a riskaverse producer is expected to use forward pricing methods to manage price risk. Farmers who perceive forward pricing to be an effective method for reducing price risk may prefer the free market system, whereby they are exposed to possible profitable opportunities, rather than to a regulated system. Forward pricing methods may be used to protect the farmer against downside risk, hence the expectation that the use of forward pricing methods would be more likely. The last two variables include the proportion of farmland that the farmer rents and whether the farmer has some form of tertiary education. Jordaan and Grové (2007) argue that only prosperous farmers would rent additional farmland. The higher human capital level of prosperous farmers, as well as that of farmers with some form of tertiary education suggests that they would be able to use more sophisticated marketing techniques, such as forward pricing.

An important factor that could influence the adoption of forward pricing is that financial institutions have recently required adequate levels of crop insurance and price risk management before financing production loans. ${ }^{5}$ Unfortunately the database offered by Jordaan and Grové (2007) does not consider the impact of production financing requirements on farmers' forward pricing behaviour. Future research should consider quantifying the significance of production financing requirements.

The discussion of the factors that are hypothesised to influence the quantity decision concludes this section. The next section covers the presentation and discussion of the results obtained from the regression analysis.

3

\section{Results and discussion}

The estimation results of the Tobit (TOBIT), Probit (PROBIT) and truncated regression (TRUNC) model specifications are presented in Table 3. Because the objective of this study is to identify factors that significantly influence forward pricing behaviour, the marginal effects for the TOBIT and PROBIT model specifications have not been calculated.

The results from the regression analyses indicated that significant differences exist between results obtained with the alternative model specifications. Since the TOBIT specification models the quantity decision taking the information set of the non-adopters into account, the TOBIT specification is expected to capture the factors that significantly affect the adoption and quantity forward priced in the PROBIT and TRUNC model specifications. However, three different types of discrepancies were observed between modelling forward pricing behaviour within a single decision-making 
framework and modelling the quantity decision conditional to the adoption decision with the Cragg model specification. Firstly, the TOBIT model identified marketing skills as a significant factor affecting forward pricing behaviour, while it was insignificant in the other models. Secondly, the variables that were significant in all three specifications have inconsistent signs across model specifications. The proportion of farm land rented and centre pivot adoption were found to be positively related to forward pricing in the TOBIT and PROBIT models while these variables were negatively related to the quantity forward priced in the TRUNC model. Lastly, the single decision-making framework failed to identify all the factors related to the adoption and extent of the use of forward pricing as a price risk management strategy. Risk aversion and specialisation were found to significantly affect the adoption and quantity decision, while offfarm economic activities, free market preference and forward pricing perception were associated exclusively with the quantity forward priced in the TRUNC model.

The highly significant $(\mathrm{p}<0.01)$ log-likelihood test ratio of 51.8 strongly rejects the TOBIT model specification in favour of the more general Cragg model specification. By implication, the variables that influence the adoption of forward pricing and the proportion crop forward priced are different. Modelling forward pricing behaviour within a single decision-making framework will therefore fail to identify the correct factors affecting forward pricing behaviour.

Table 3:

Regression results for alternative model specifications when modelling forward pricing behaviour

\begin{tabular}{|c|c|c|c|}
\hline & Single decision & Adoption decision & Quantity decision \\
\hline & TOBIT & PROBIT & TRUNCATED \\
\hline Dependent variable & $\begin{array}{l}\text { Proportion of crop } \\
\text { forward priced }\end{array}$ & $\begin{array}{c}\text { Dummy }=1 \text { if } \\
\text { forward priced, } \\
\text { otherwise } 0\end{array}$ & $\begin{array}{l}\text { Proportion of crop } \\
\text { forward priced }\end{array}$ \\
\hline Variable & Coefficient & Coefficient & Coefficient \\
\hline Intercept & $\begin{array}{l}-285.9492^{* * *} \\
(102.8162)\end{array}$ & $\begin{array}{l}-5.8572 * * * \\
(2.1516)\end{array}$ & $\begin{array}{l}94.9121^{* * *} \\
(31.0193)\end{array}$ \\
\hline Marketing skills & $\begin{array}{l}26.1919^{*} \\
(14.3220)\end{array}$ & $\begin{array}{c}0.3890 \\
(0.2702)\end{array}$ & $\begin{array}{c}1.2318 \\
(5.2443)\end{array}$ \\
\hline Off-farm economic activities & $\begin{array}{l}-0.5304 \\
(0.4957)\end{array}$ & $\begin{array}{l}-0.004 \\
(0.0102)\end{array}$ & $\begin{array}{l}-0.3220^{* * *} \\
(0.1189)\end{array}$ \\
\hline Proportion farmland rented & $\begin{array}{l}111.6052^{* *} \\
(51.6135)\end{array}$ & $\begin{array}{l}1.8792 * * \\
(0.9507)\end{array}$ & $\begin{array}{l}-31.9793^{*} \\
(16.6708)\end{array}$ \\
\hline Free-market preference & $\begin{array}{c}5.7048 \\
(6.2514)\end{array}$ & $\begin{array}{l}0.1101 \\
(0.1226)\end{array}$ & $\begin{array}{l}3.7490^{* *} \\
(1.8931)\end{array}$ \\
\hline Risk aversion & $\begin{array}{r}-1.4042 \\
(0.9158)\end{array}$ & $\begin{array}{l}-0.0376^{*} \\
(0.0196)\end{array}$ & $\begin{array}{l}0.5679 * * \\
(0.2415)\end{array}$ \\
\hline Specialisation & $\begin{array}{l}225.9912 \\
(142.1988)\end{array}$ & $\begin{array}{l}6.1840^{* *} \\
(3.0563)\end{array}$ & $\begin{array}{c}-175.1720^{* * *} \\
(46.5830)\end{array}$ \\
\hline
\end{tabular}




\begin{tabular}{|c|c|c|c|}
\hline \multirow{2}{*}{ Insurance } & 64.8535* & $1.3275^{*}$ & 12.4512 \\
\hline & $(35.7555)$ & $(0.7379)$ & (10.7598) \\
\hline \multirow[t]{2}{*}{ Centre pivot adoption } & $69.0796^{* *}$ & $1.7767^{* * *}$ & $-17.4989 * *$ \\
\hline & $(29.1775)$ & $(0.6633)$ & $(7.9190)$ \\
\hline \multirow[t]{2}{*}{ Forward pricing perception } & -7.0853 & -0.2627 & $30.1375^{* * *}$ \\
\hline & $(27.6404)$ & $(0.5061)$ & $(8.8375)$ \\
\hline \multicolumn{4}{|l|}{ GOODNESS OF FIT } \\
\hline No. of observations & 47 & 47 & 47 \\
\hline \multirow[t]{2}{*}{ Sigma } & $63.9069 * * *$ & & $11.7946^{* * *}$ \\
\hline & $(11.4854)$ & & $(1.867)$ \\
\hline Log likelihood & -124.1196 & -20.4924 & -77.7269 \\
\hline McFadden $\mathrm{R}^{2 a}$ & & 0.3607 & \\
\hline Model chi-square ${ }^{b}$ & & 23.1245 & \\
\hline Significance level $^{\mathrm{c}}$ & & 0.0059 & \\
\hline LR test for TOBIT vs & & & $51.8005^{d}$ \\
\hline truncated regression & & & $(0.0000)^{\mathrm{e}}$ \\
\hline
\end{tabular}

Note: ${ }^{* *},{ }^{* *}$, and $*$ indicates statistical significance at 1 per cent, 5 per cent and 10 per cent respectively, and standard errors are in parentheses.

a McFadden $\mathrm{R}^{2}$ is given by one minus the ratio of the unrestricted to restricted log likelihood function values.

b The chi-square test evaluates the null hypothesis that all coefficients (not including the constant) are jointly zero.

c,e Numbers in parentheses are associated with chi-square probabilities.

${ }^{d}$ The likelihood ratio test is given by $\lambda=2\left(\ln \mathrm{L}_{\text {Probit }}+\ln \mathrm{L}_{\text {Truncated regression }}-\ln \mathrm{L}_{\text {Tobit }}\right)$.

The factors affecting the adoption of forward pricing methods in price risk management are discussed in detail by Jordaan and Grové (2007). These researchers concluded that their sample of farmers perceived forward pricing as a risky marketing alternative. The adoption decision is further influenced by factors that are predominantly associated with higher levels of human capital. The factor analysis conducted by Jordaan and Grové (2007) on the personal reasons restricting the respondents from using forward pricing methods confirmed that finding by identifying lack of capacity as a major factor restricting them from using forward pricing methods. Contrary to the adoption decision, the TRUNC results suggest that once farmers adopted the use of forward pricing methods, risk aversion increased the proportion of the crop they were willing to forward price. Moreover, those who adopted forward pricing methods tended to use a portfolio of risk management strategies to reduce their exposure to overall risk on their farm businesses. For example, a higher level of specialisation in the production of one crop (higher levels of human capital) is significantly $(\mathrm{p}<0.05)$ positively related to the adoption of forward pricing behaviour. However, once the adoption decision has been made, the same variable is significantly $(\mathrm{p}<0.01)$ negatively related to the quantity forward priced. The sample of farmers thus uses diversification (inverse of specialisation) to substitute for the quantity of their maize crop that is forward priced. Off-farm economic activities and centre pivots were also identified as a substitute for forward pricing by the TRUNC model. Insurance was insignificantly related to the forward priced proportion of the crop. 


\section{4}

\section{Conclusions and recommendations}

The main objective of this research was to compare the results of modelling forward pricing behaviour within a single decisionmaking framework with the results obtained by modelling the quantity decision conditional to the adoption decision in a two-step approach. Modelling forward pricing behaviour as a single decision is based on the assumption that the same variables influence the two forward pricing decisions. The log-likelihood ration test (Greene, 2008) confirmed that modelling forward pricing behaviour as a single decision is inappropriate, as different variables influence the adoption and quantity decisions differently. In assuming a single decision-making framework, the analyst would have failed to identify the important influence of risk aversion on the use of forward pricing behaviour. The results thus also confirm the argument of McNew and Musser (2000) that risk aversion is the primary driving force behind the use of forward pricing methods. It should be recognised that risk aversion may also be the reason why farmers do not use forward pricing methods. Apart from its failure to expose the respondents' perception that forward pricing is a risky marketing alternative, the TOBIT specification also failed to expose the fact that farmers who adopted forward pricing methods tend to use a portfolio of risk management tools to reduce their exposure to overall risk. Using the TOBIT model specification therefore also fails to identify the necessity of educating farmers in the use of a portfolio of risk management tools instead of only forward pricing methods. Modelling forward pricing behaviour as two separate decisions clearly resulted in more information being exposed relating to factors that influence forward pricing behaviour.

Drawing conclusions based on the results obtained from a model that forces variables to influence a decision in a certain way may have serious implications. It may overlook the importance of specific factors which have a major restrictive impact on the use of forward pricing methods. Using such information in the compilation of educational material used to educate farmers in the use of forward pricing methods may even possibly explain the lack of growth in the number of people who use forward pricing methods. Thus, based on the results from this research, it can be concluded that the two-step approach suggested by Katchova and Miranda (2004) is more effective for modelling forward pricing behaviour than the TOBIT model, which was used in previous research.

\section{Acknowledgements}

Financial assistance provided by the National Research Foundation (NRF) is gratefully acknowledged. The views of the authors do not necessarily reflect those of the NRF.

\section{End notes}

1 Although Vaalharts has no SAFEX-certified silo, there is no reason why its absence should influence the adoption of hedging methods. At harvest, producers who hedged against price risk using a futures contract could sell their crops in the spot market, after which they could offset the futures position by buying back a similar futures contract prior to the delivery date.

2 The number of farmers initially drawn from the database was slightly higher than 78 to account for subject mortality (Strydom et al., 2003).

3 The fact that only 50 of the respondents actually did produce maize means that the number of respondents is lower than the suggested guidelines for sample size. By implication, the lower number of respondents may lead to possible bias in the results, which may have a negative influence on the ability to generalise the results obtained to the general population of irrigation farmers in Vaalharts. By implication, the results could also not be generalised to be representative of maize farmers in South Africa.

4 Initially the Tobit model specification was compared with a logit and OLS regression model specification. The observation by the editorial board that the Tobit model specification assumes an underlying Probit model led to the adoption of the Cragg model specification.

5 We are grateful to an anonymous reviewer for pointing out the importance of considering production finance requirements on the forward pricing behaviour of farmers. 


\section{References}

ASPLUND, N.M., FORSTER, D.L. \& STOUT, T.T. 1989. Farmers' use of forward contracting and hedging. Review of Futures Markets, 8: 24-37.

BAYLEY, B. 2000. A revolution in the market: The deregulation of South African agriculture. Oxford Policy Management.

BOWN, A.N., ORTMANN, G.F. \& DARROCH, M.A.G. 1999. Use of maize marketing alternatives and price risk management tools by commercial maize farmers in South Africa. Agrekon, 38(3): 275-301. BOWN, A.N., ORTMANN, G.F. \& DARROCH, M.A.G. 2000. Factors affecting the use of price risk management tools by large commercial maize producers in South Africa. South African Journal of Economic and Management Sciences NS 3(1): 75-96. CRAGG, J.G. 1971. Some statistical models for limited dependent variables with application to the demand for durable goods. Econometrica, 39(5): 829-824.

DAVIS, T.D. 2005. Forward pricing behaviour of corn and soybean producers. Journal of Agricultural and Applied Economics, April.

GOODWIN, B.K. \& SCHROEDER, T.C. 1994.

Human capital, producer education programs, and adoption of forward pricing methods. American Journal of Agricultural Economics, 76: 936-947.

GREENE W.H. 2008. Econometric analysis. (6 $6^{\text {th }} \mathrm{ed}$.) Upper Saddle River: Prentice Hall. GROENEWALD, J., GELDENHUYS, F., JOOSTE, A., BALYAMUJURA, H. \& DOYER, T. 2003. Die bemarking van landbouprodukte in die nuwe millenium. Eerste Nasionale Bank Landboudivisie.

GUJARATI, D.N. 2003. Basic econometrics. $\left(4^{\text {th }}\right.$ ed.)

New York: McGraw-Hill Higher Education.

HEIJ, C., DE BOER, P., HANS-FRANSES, P., KLOEK, T. \& VAN DIJK, H.K. 2004. Econometric methods with applications in business and economics, Oxford University Press: 463-474.

ISENGILDINA, O. \& HUDSON, M.D. 2001. Factors affecting hedging decisions using evidence from the cotton industry. Paper presented at the NCR-134 Conference on Applied Price Analysis, Forecasting, and Market Risk Management. St. Louis, Missouri, April 23-24.
JORDAAN, H., GROVÉ, B., JOOSTE, A. \& ALEMU, Z.G. 2007. Measuring the price volatility of certain field crops in South Africa using the ARCH/ GARCH approach. Agrekon, 46(3): 306-322. JORDAAN, H. \& GROVÉ, B. 2007. Factors affecting maize producers' adoption of forward pricing in price risk management: The case of Vaalharts. Agrekon, 46(4): 548-565.

JORDAAN, H. \& GROVÉ, B. 2008. Factors affecting the use of forward pricing methods in price risk management with special reference to the influence of risk aversion. Agrekon, 47(1): 102-115.

KATCHOVA, A.L. \& MIRANDA, M.J. 2004. Twostep econometric estimation of farm characteristics affecting marketing contract decisions. American Journal of Agricultural Economics, 86(1): 88-102. LIN, T. \& SCHMIDT, P. 1984. A test of the Tobit specification against an alternative suggested by Cragg. The Review of Economics and Statistics, 66(1): 174-177. MCNEW, K. \& MUSSER, W. 2000. Evidence of farmers' forward pricing behaviour. Working Paper 00-02. Department of Agricultural and Resource Economics. University of Maryland.

MEYER, F. 2005. An alternative tariff dispensation for the South African wheat industry. Bureau for Food and Agricultural Policy Research, Department of Agricultural Economics, Extension, and Rural Development, University of Pretoria.

MUSSER, W.N., PATRICK, G.F. \& ECKMAN, D.T. 1996. Risk and grain marketing behaviour of largescale farmers. Review of Agricultural Economics, 18: 65-77.

SARTWELLE, J., O'BRIEN, D., TIENEY, W. \& EGGERS, T. 2000. The effect of personal and farm characteristics upon grain marketing practices. Journal of Agricultural and Applied Economics, 32(1): 95-111. SHAPIRO, B.I. \& BRORSEN, B.W. 1998. Factors affecting farmers' hedging decisions. North Central Journal of Agricultural Economics, 10: 145-153. STRYDOM, H., FOUCHÉ, C.B. \& DELPORT, C.S.L. 2003. Research at grass roots for the social sciences and human services professionals. ( $2^{\text {nd }}$ ed.) Van Schaik Publishers.

VAN ROOYEN, J. 1999. How relevant will the use of derivative instruments be for maize marketing in the future? Agrekon, 38(4): 659-669. 